\title{
Model of managing the professional-educational route of a future specialist
}

\author{
Um modelo de gestão da trajetória profissional e educativa de \\ especialista future
}

\section{Modelo de gestión de la trayectoria profesional y educativa de un futuro especialista}

\author{
Alexander A. Fedorov ${ }^{1}$ (D), Elena V. Mialkina ${ }^{1}$ iD, Ekaterina P. Sedykh ${ }^{1}$ (i), \\ Valeriya A. Zhitkova ${ }^{1}$ iD
}

${ }^{1}$ Minin Nizhny Novgorod State Pedagogical University, Nizhny Novgorod, Russian Federation.

Corresponding Author:

Alexander A. Fedorov

Email: fedorov_aa@mininuniver.ru

\begin{abstract}
How to cite: Fedorov, A. A., Mialkina, E. V., Sedykh, E. P., \& Zhitkova, V. A. (2021). Model of managing the professional-educational route of a future specialist. Revista Tempos e Espaços em Educação, 14(33), e16325. http://dx.doi.org/10.20952/revtee.v14i33.16325
\end{abstract}

\section{ABSTRACT}

The research problem is the process and result of diagnostics of targeted forming the trajectory of professional development of a personality. This problem is especially important under the modern conditions of mobility in professional sphere and the growing requirements for activity of a professional. The method of analyzing the system of professional guidance in a region enabled to reveal the main requirements and characteristics of the process of professional selfdetermination. As a result of the study of the theory and practice of professional guidance and professional self-determination processes, a model was elaborated for managing the professionaleducational route of a future specialist. Special attention is paid to the stage of professional diagnostics and professional navigation of schoolchildren and university matriculants, based on the existing methods of professional guidance. A conclusion was made that a complex approach is needed for the processes of professional development of a personality and the support of professional development of future specialists, with a view of synchronizing the resources of regional educational establishments of various levels, consolidation of the efforts of the regional administration, employers and educational sphere of the region. The authors present a description of an electronic service "Employee Constructor", which provides management of personal professional-educational route of a personality during growing, professional formation, professional adaptation and development, depending on the interests, abilities, individual features, competencies and experience of a particular person.

Keywords: Support of professional activity. Professional guidance. Career development. 


\section{RESUMO}

O problema de pesquisa é o processo e resultado do diagnóstico de alvos formando a trajetória de desenvolvimento profissional de uma personalidade. Este problema é especialmente importante nas condições modernas de mobilidade na esfera profissional e nas crescentes exigências para a atividade de um profissional. O método de análise do sistema de orientação profissional de uma região permitiu revelar os principais requisitos e características do processo de autodeterminação profissional. Como resultado do estudo da teoria e prática da orientação profissional e dos processos de autodeterminação profissional, foi elaborado um modelo de gestão do percurso profissional-educacional de um futuro especialista. É dada especial atenção à fase de diagnóstico profissional e navegação profissional de alunos e matriculados universitários, com base nos métodos existentes de orientação profissional. Concluiu-se que é necessária uma abordagem complexa para os processos de desenvolvimento profissional de uma personalidade e o apoio ao desenvolvimento profissional de futuros especialistas, com vista a sincronizar os recursos dos estabelecimentos regionais de ensino dos vários níveis, consolidação dos esforços do administração regional, empregadores e esfera educacional da região. Os autores apresentam a descrição de um serviço eletrônico "Employee Constructor", que proporciona a gestão do percurso pessoal profissional-educacional de uma personalidade durante o crescimento, formação profissional, adaptação e desenvolvimento profissional, em função dos interesses, capacidades, características individuais, competências e experiência de uma pessoa em particular.

Palavras-chave: Apoio à atividade profissional. Orientação profissional. Desenvolvimento de carreira.

\section{RESUMEN}

El problema de investigación es el proceso y resultado de los diagnósticos de focalización que forman la trayectoria de desarrollo profesional de una personalidad. Este problema es especialmente importante en las condiciones modernas de movilidad en la esfera profesional y las crecientes exigencias para la actividad de un profesional. El método de análisis del sistema de orientación profesional en una región permitió revelar los principales requisitos y características del proceso de autodeterminación profesional. Como resultado del estudio de la teoría y la práctica de los procesos de orientación profesional y autodeterminación profesional, se elaboró un modelo para la gestión de la ruta profesional-educativa de un futuro especialista. Se presta especial atención a la etapa de diagnóstico profesional y navegación profesional de escolares y matriculados universitarios, en base a los métodos existentes de orientación profesional. Se concluyó que se requiere un abordaje complejo para los procesos de desarrollo profesional de la personalidad y el apoyo al desarrollo profesional de los futuros especialistas, con miras a sincronizar los recursos de los establecimientos educativos regionales de diversos niveles, consolidación de los esfuerzos de la administración regional, patronal y ámbito educativo de la región. Los autores presentan una descripción de un servicio electrónico "Employee Constructor", que brinda la gestión de la ruta personal profesional-educativa de una personalidad durante el crecimiento, formación profesional, adaptación y desarrollo profesional, en función de los intereses, habilidades, rasgos individuales, competencias y experiencia. de una persona en particular.

Palabras clave: Apoyo a la actividad profesional. Orientación profesional. Desarrollo de carrera.

\section{INTRODUCTION}

Professional self-determination, formation and development of a personality is a multidimensional and multi-aspect process, implying stage-by-stage decision-making, forming balance between personal interests and needs of a society. 
The experience of the Russian and foreign theory and practice of professional formation of a personality allows distinguishing the key issues of this process (Batyshev, 1997):

- incomplete process of professional self-determination (matriculation into an educational establishment is accidental);

- low quality of the made and implemented decision (at the beginning of studies, facts are revealed which had not been taken into account before);

- $\quad$ poor understanding of oneself, one's own abilities, values, wishes, qualities;

- $\quad$ perfunctory idea of the chosen profession, of the aims, content and means of the future professional activity, of the professionally important qualities, variants, features of the future employment;

- $\quad$ vague idea of the educational and professional prospects and the plan of mastering the profession.

At the stage of professional development, the problems of insufficient vision of the life and professional goals and the professional trajectory are complemented by such difficulties as the lack of professional skills, insufficiently formed certain professionally important qualities, insufficient preparedness to adaptive behavior in the labor market, more and more significant are the factors of individual competency, efficiency and competitiveness, which determine the importance of personified approach to support as professional activity, as well as of preprofessional navigation.

The traditional approaches, using the standard methods of assessing the preparedness for professional activity by dividing into categories (age and professional) are inadequate, as they require complex support, including not only standard decisions, but also individual diagnostics, consultations, monitoring of professional development and professional retraining throughout life.

In these conditions, the traditional professional guidance should be reconsidered taking into account the need for personal and effective support of specialists of various ages under turbulence of the environment and challenges of time. Interaction with all organizations of the region is required to create an integrated system of social-pedagogical activities aimed at forming the inner need of a personality for self-implementation of the conscious choice of the profession, topical for social production, demanded in the labor market, promoting unrepeated personality development and professional growth of a specialist.

The problems of professional self-determination were studied by such foreign researchers as A. Maslow, S. Fukuyama, J. Holland, etc., who considered professional self-determination to be a set of tasks posed by the society before a personality, a process of stage-by-stage decisionmaking which helps a personality to form balance between one's preferences and abilities of the educational system (Kazakevich, n.d.; Kostenko et al., 2017).

The stages of professional development and the issues related to it are considered by the authors of conceptions of professional development: Gintsberg et al. (1986), Zeer (2005), Povarenkov (1991, 2002), Kondakov \& Sukharev (1989), McMahon, (n.d.), etc.

As a rule, researchers distinguish three or four stages of professional development: in D. Super's conception, these are the stages of growth, research, maintenance and decline (McMahon, n.d.); Zeer (2005) and Kudryavtsev (1986) distinguish initiation of professional intentions, professional training, entering into profession, implementation of a personality within the profession; Povarenkov $(1991,2002)$ lists pre-professional development of a personality, search for and selection of a profession, professional education, and independent professional activity; Gintsberg allocated the stages of fantasy, hypothetical and realistic stages (Kondakov \& Sukharev, 1989). As a rule, special attention is paid to the initial stages, referring to selfdetermination, choosing the profession or formation as a professional ("research stage" (McMahon, n.d.)), which determine the overall personal professional development. 
Various aspects of the problems of professional formation and development are considered in the works by such authors as: Blinov (2014, 2018), Balobanova (2015), Bedov (n.d.), Fedorov (2017), Markova (1996), Orlova \& Panasyuk (2015), Pakhomova et al. (2010), Rezapkina (2012, 2013, 2015), Rodionov \& Sergeev (2017), etc. Solving the problems at various stages of professional trajectory, the authors assert the necessity of systemic work in the spheres of managing the professional guidance, activating the social partnership of all participants of life-long learning system, and wide use of information-communication technologies in professional guidance.

\section{METHODOLOGY}

Choosing the professional trajectory is a long-standing process, which starts from elaborating the persona professional conception, professional self-determination, and professional formation. Then follow the stages of professional adaptation and professional development, professional maturity. At each stage of the personal professional route, a person has to make choices, overcome the difficulties of growth, and solve specific problems.

For the first time, the scientific approach to choosing a profession was applied by Frank Parsons (Tolstoguzov, 2015; Parsons, 1909). For the functioning of "Profession selection bureau", he elaborated the basic principle of profession selection, including groups of factors (clear representation of oneself, one's dispositions, abilities, interests, resources, limitations and other properties (research of the person's qualities) and awareness of requirements and conditions for achieving success (research of the professional requirements to the person) in various directions of activity) and substantiated coordination between these two groups of factors (coordination of the professional requirements with the personal properties).

The practical activity of foreign specialists in the sphere of professional guidance is aimed, first of all, at career development and is viewed as a long-standing process, embracing schoolchildren, in the first place, and oriented towards self-cognition, acquaintance with professions, development of practical thinking and self-organization of the schoolchildren, acquisition of practical skills, professional education and career planning; the techniques used include interviews, testing, seminars, and consultations (Kozyreva, n.d.; Romanova, 2013; A Career Guidance Policy and Strategy for Compulsory Schooling in Malta, 2007; Jenschke et al., n.d.; Career Guidance in Sweden , 2015; Career Education and Guidance in New Zealand Schools, 2009; Career guidance and counseling, n.d.; Careers guidance in school, colleges and universities, n.d.; Careers guidance and access for education and training providers, n.d.; Educational and vocational guidance in Finland, n.d.; Ricci \& Boccardi, n.d.; Oriol et al., n.d.; Stefansdottir, n.d.; Vehbi, 2014; Vocational guidance education in full-time compulsory education, n.d.). The following approaches are most frequently used in the works devoted to the practice of professional guidance, psychological-pedagogical support of predicting the professional and personal development of an individual: systemic, competence, activity, project, personality-oriented (Blauberg, 1997; Zimnyaya, n.d.; Kazakevich, n.d.; Kolesnikova et al., 2011; Kuzmina, 1990; Mishina \& Yavgildina, 2016; Tartur, 2004; Troitskaya, n.d.; Chistyakova \& Zaharov, 1987.

Systemic approach (Blauberg, 1997; Kolesnikova et al. (2011) is built on the conception of unity of interconnected elements, resulting in forming a common space of professional guidance, accessible for all subjects of the process.

Competence approach (Zimnyaya (n.d.), Tartur (2004), Troitskaya (n.d.)) implies, first of all, forming competences and professionally-significant qualities in the course of training.

Activity approach (Mishina \& Yavgildina, 2016) is based on forming the intellectualinformational support of professional activity of a subject under the conditions of rapidly changing professional environment, providing the understanding of the processes of obtaining, 
comprehending, and analyzing information, and projecting more efficient models and means of career trajectories' construction.

By project approach in professional guidance (Bedov (n.d.), Pisareva (2005), Zapesotskaya (2006), the key element is a set of individual and group projects aimed at implementation of prognostic plans of professional and personal development. Each project of forming the personal future goes through the following stages: prognosis, implementation, assessment of the implemented project, its specification and forming a new variant of personal and professional development.

According to the personality-oriented approach (Klimov (1996), Pryazhnikova \& Pryazhnikov (2010)), the central driving force of prognosis is the personality per se, its need for self-analysis and self-development of its personal-professional potential. Orientation at the personality's future means that prognosis will be subject to satisfying the personality's need for professional activity. Building the individual trajectory of a personality with the account of his/her motives, interests, and values is aimed at development and self-development of social and professionally significant qualities and forms of behavior. The leading motives are prospects of professional future of a specialist.

When considering the issues related to the effective management of professionaleducational route, the following principles are distinguished, which directly influence building career trajectories:

- principle of developing a personality in the educational-professional space: based on comprehension of the probable and actual, potential and real self-development of a personality. This principle implies adaptation of a personality to the changing systems of education, multidimensional professional activity, and social-economic situation.

- principle of interaction: it focuses the attention of the psychologists, who support the process of professional future projecting, onto individual development of a personality and professional development. The personality characteristics, such as motives, interests, abilities, individual features, competencies, experience, together with characteristics of individuality heredity, specific properties of the body, state of health, physical and mental energy - determine the educational and professional achievements.

- principle of social mobility: it determines the possibility of a personality self-organization in order to form alternative scenarios of professional future in the changing world of professions. This principle implies correlation of one's personal-professional qualities with characteristics of professions and requirements of employers.

- principle of prognostic alternative: it implies the probabilistic character of professional future. The trajectories of professional future are determined by the vectors of predicted goals and the terms of achieving them, as well as by social-economic situation. The assessment of the fulfilled prognosis and the probability of its fulfillment are essential.

In the present research, we used complex approach, integrating and creatively transforming the above approaches and principles, taking into account the need to identify the special abilities and personal preferences of a future specialist, the monitoring of professional competencies, the continuous and anticipatory learning with a view of advancing the professional level of a person and mastering several professions.

The need to introduce such a system is linked with the necessity to form the personal preparedness of a future specialist to solve the career problems in aggregate with the issues of personality self-determination and personality growth.

\section{RESULTS}

Based on the above approaches, we elaborated a regional model of managing professionallife route of future specialists (Fig. 1). The model mission is unique professional development of a 
personality throughout life through determination of variable educational and career trajectories, facilitating the achievement of the desired level of professional and personal development and formation of the personal future in the context of prospective directions of development in the region.

The model functional is provided by a system consolidating information about personal professional inclinations at all stages of professional formation and development, ensuring support and correction of professional activity in compliance with individual professional trajectory and facilitating unique professional development of a personality throughout life [48].

The model was elaborated at Minin University, within the program of the University transformation into a center of social development of the region.

The model is based on systemic, competence, activity, project, and personality-oriented approaches, which are revealed in the principles of interaction, personality development, social mobility and alternative.

The general functions of the model include: regulating, informative, managerial, organizational, and assessing.

The regulating function provides effective coordination of activity of the regional authorities in the sphere of developing and effective employment of human resources, based on intersectoral state-supported approach to professional guidance and psychological support of professional formation and development of the region population.

The informative function serves for providing all participants with the necessary information about the professions which interest them, the requirements for a personality in a particular profession; personality features, possibilities and means to develop a particular skill necessary for acquisition and further employment in the chosen sphere, about the possibilities for training and prospects of employment in the chosen sphere in the region.

The managerial function facilitates the rational organization of decision-making activity with a view of planning and managing the processes of elaboration, introduction and implementation of comprehensive professional diagnostics and guidance in the region.

The organizational function regulates the process of distributing responsibilities and coordinating efforts of tutors, psychologists, educational establishments, and representatives of regional authorities in supporting the activities in the sphere of professional guidance, professional development and professional counseling of a personality throughout life.

The assessing function ensures unified interpretation of measurements, qualitative and quantitative estimations, prognosis, quality of the achieved results in the sphere of professional diagnostics and guidance.

The model is centered on the processes of forming and managing the individual professional-educational route of a personality from choosing the professional conception till achieving the status of a tutor, while these processes are implemented in the context of strategic plan of the regional development.

Forming the professional conception at school age is a result of comprehensive informational and organizational-practical influence of the family, educational and community establishments, which provide assistance in choosing professional activity with the account of individual interests, inclinations, and abilities of a personality, and the needs of regional development. 
Figure 1. Model of management of professional and educational route of future specialists

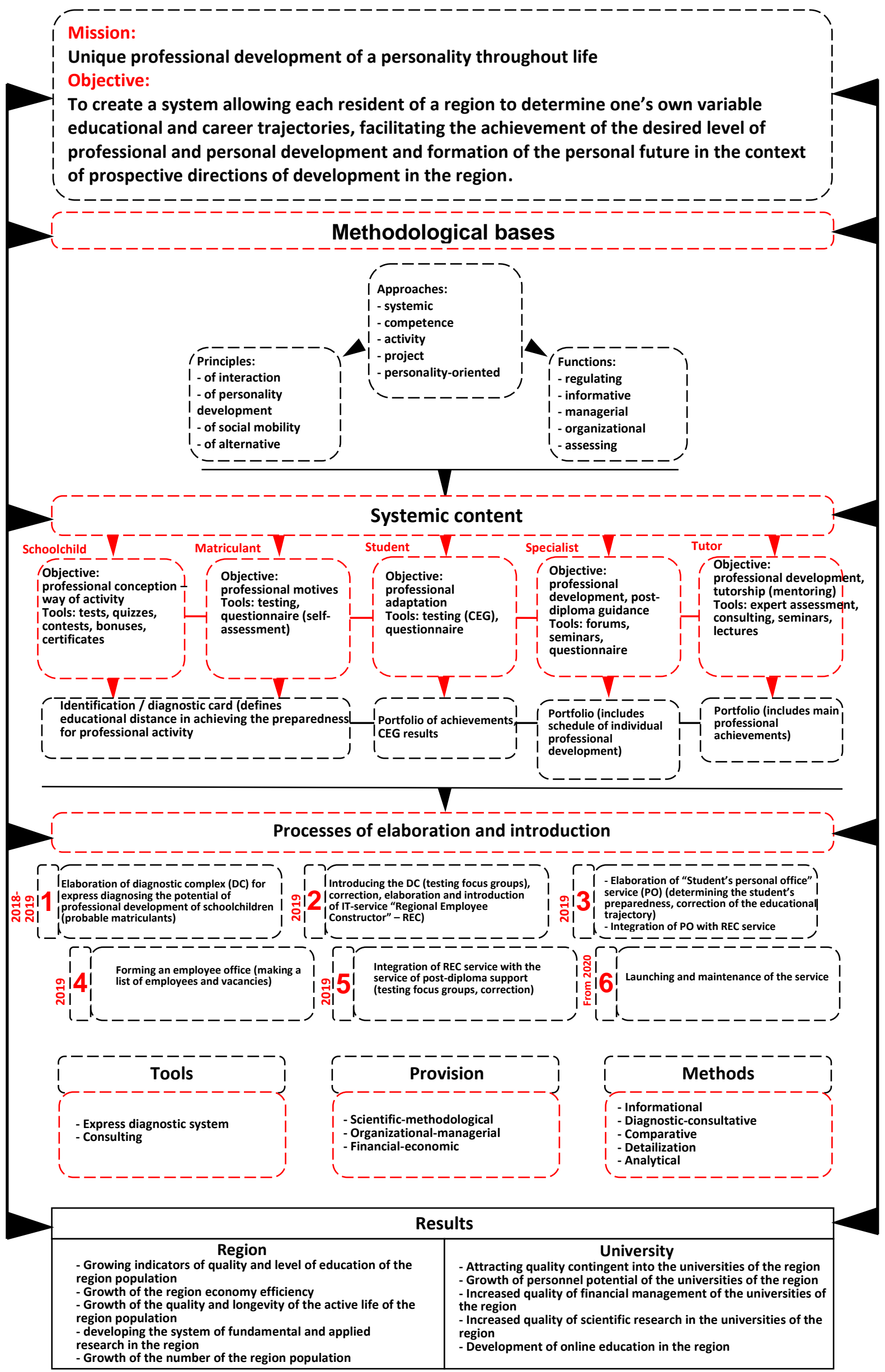


Forecasting the professional future of a personality (professional motives) is reconstruction of anticipatory prospects of personal development, psychological-pedagogical preparation for the new events and processes of a person's living cycle. An essential role in the anticipatory reflection of a professional future of a personality is played by the created conception of the world of professions, the objective assessment of one's abilities, capabilities of employment and variants of career trajectories.

The goal of projecting the personal educational and career trajectories is anticipation of the desired results and prospects of personal development, taking into account the directions and scales of economic development of the region of residence.

At the stage of professional guidance of the matriculants, the following is taken into account: directions of strategic development of a region, availability of long-term vacancies, and specter of the programs implemented by the regional educational establishments of professional education for the opportunity to get high-quality professional education and further employment in the sphere of the obtained profession in the region.

The structure of projecting the personal educational and career trajectories is built on short-term (less than one year), middle-term (one to five years) and long-term target goals and takes into account the other living goals of the person.

Support of the professional activity of a specialist is carried out throughout professional life (professional adaptation, professional development, tutorship), taking into account the constant specification of the goals and terms of implementation of the professional development plans; it is shaped as individual professional route, which determines the personal educational and career trajectory and is structured in certain age and time intervals.

Psychological-pedagogical support of a personality, taking into account the results of studies, professional achievements, additional education (portfolio), and the forecasts of the regional labor market development and social-economic situation in the region, includes recommendations on correcting the professional plans, ways and means of coping with negative phenomena and processes of professional development.

\section{DISCUSSION}

Introducing the model of managing the professional-educational route of future specialists implies implementation of the following processes:

- elaboration of a diagnostic complex for express diagnostics of the potential of professional development of 8-9 and 10-11-grade schoolchildren;

- elaboration and introduction of IT-services in "Employee Constructor" format, organization of focus groups' testing with this service;

- elaboration of "Student's personal office" service and its integration with "Employee Constructor" service;

- forming the employees' office, the main informational base of which is information about regional employers and vacancies;

support; integration of "Employee Constructor" service with the service of post-diploma

- $\quad$ launching of the integrated service and its maintenance.

All processes imply scientific-methodological, organizational-managerial and financialeconomic provision.

During the model elaboration and introduction, the informational, diagnostic-consultative, comparative, analytical methods are used, as well as the method of detailization, which imply individual work with each subject in order to build an individual trajectory of professional and personal development. 
Formation of the individual trajectories of professional development of future specialists is influenced by the variety of professional qualifications, stipulated by professional standards, and the logic of mastering a particular job, profession, or position. The meaning-making factor of forming the individual professional trajectory is independent and conscious choice of the vector of development among the possible alternatives. The choice and building of personal professional trajectories are based on social-economic conditions and situation in the market of educational services, demand of the regional economy for personnel, as well as individual characteristics of the personality: social-professional orientation, experience, level of education, individualpsychological abilities, state of health.

The individual trajectories of professional development combine the past, the present and the future of a personality. Unfolding of these trajectories takes place in time, while the changes in the directions of their development are determined by the events significant for the personality: external - matriculation into an educational establishment, graduation, employment, change of the place of residence, etc.; internal - psychological crises, intrapersonality conflicts.

Projecting the individual professional trajectories includes the following stages (Zeer \& Symanyuk, 2014):

- $\quad$ actualization of the need for personally-significant achievement of a certain result: social-professional recognition, qualification, position, status;

- $\quad$ reflection over the professional-educational past;

- constructing the image of the desired future;

- elaboration of the goals and tasks for activities at various time intervals of professional trajectories;

- $\quad$ monitoring of implementation of individual educational trajectory and correcting it;

- $\quad$ making a portfolio of professional-educational achievements and verification of the forecast of professional future (determining the degree of its reliability and relevance).

Implementation of the proposed model ensures:

- $\quad$ increase of the standard of living of the region population, based on improving the quality of professional activity and increasing the potential of professional development of every specialist working in the region;

- improved quality of the regional system of professional education, including online education, growth of the qualitative indicators of the educational establishments in the region;

- $\quad$ development of the regional system of fundamental and applied scientific research;

- $\quad$ growth of efficiency of the regional economy in general.

Introducing the model will allow to broaden professional guidance among middle-school students, and over the longer term - among primary school children, at the same time qualitatively changing not only the system of schoolchildren's abilities diagnosing but also the system of methodological and consultative work in the sphere of choosing professional guidelines, elaborating professional conceptions and making a pre-professional choice. Also, Introducing the model will allow to broaden the limits of post-diploma support of graduates by transforming the activity towards maintenance of continuous professional and personality development of specialists and forming the system of tutorship.

The implementation of the model of managing the professional-educational route of future specialists is based on a set of informational services, providing the growth of efficiency of personal professional activity, operative analysis and correction of professional trajectory of a personality, taking into account the features of personality development and the strategic regional development.

The key service is the Open regional electronic service in the format of "Employee Constructor", providing the management of personal professional-educational route during maturing, professional formation, professional adaptation and development, taking into account 
the interests, abilities, individual features, competencies and experience of each person, as well as the priorities and prospects of the regional strategic development. The service is targeted at three groups of users: schoolchildren (matriculants), university students, and university graduates (young specialists) of the region.

For matriculants, the service offers building an individual educational trajectory depending on the inclination to a particular profession (revealed by express diagnostics during the middle and senior school grades): choosing subjects for the Unified State Exam, a list of resources for training for the Unified State Exam, a list of regional educational establishments of professional education, a list of educational programs with levels and forms of education, examples of vacancies for further employment in the region.

For the students of regional universities, the service offers additional options, based on integration with the data of informational-educational environment of the chosen regional university: electronic courses, schedule, option for obtaining additional competencies, including with the resources of extracurricular activity, electronic portfolio of the experience and achievements, ranking of students' activity.

For the young specialists (university graduates), over the longer term, the service will offer support of professional adaptation and building individual career trajectories, based on integration with the subsystem of post-diploma support, through analysis of such factors as education results, professional achievements, desire to get additional education, mobility within the region, consent to temporary employment.

\section{CONCLUSION}

Thus, the model of managing the professional-educational route of future specialists implies complex support of professional self-determination, professional implementation, career growth, personality development and personal success, providing: pre-professional selfdetermination (revealing special abilities and interests) as a result of work with 8-9 and 10-11 grades schoolchildren; pre-professional development and monitoring (testing not less than once a year, providing individual recommendations of consultants); building an individual route of professional and professional development during studies (a first-year student has a ready individual route of professional and personality growth); monitoring of professional adaptation and professional activity (maintenance of a specialist's portfolio); individual support and development in professional activity (arranging consultations, seminars; creating professional associations and maintaining their activity); creating the system of tutorship.

The model of managing the professional-educational route of future specialists is topical and effective both at the regional level and at the level of individual organizations and citizens.

Consolidated activity of the regional universities, which train and support the specialists employed by the regional organizations, meeting the qualification requirements and possessing the necessary professional competencies, and the regional authorities, aimed at developing the system of professional guidance ensures the growth of professional education quality and longevity of the active professional life of the region's population, which, in turn, improves the economic, social and demographic situation in the region (Myalkina, 2011; Prokhorova \& Sedykh, 2016).

The educational establishments of general education get access to consolidated informational system of professional guidance interacting within the system of online consultations and comprehensive methodological support.

Thus, in the region, conditions are created for forming stable professional communities specialists of new type, willing to work actively throughout their career, to work in the region and for the purposes of the region development. 
Authors' Contributions: Fedorov, A. A.: acquisition of data, analysis and interpretation of data, drafting the article; Mialkina, E. V.: conception and design, analysis and interpretation of data, critical review of important intellectual content; Sedykh, E. P.: drafting the article, critical review of important intellectual content; Zhitkova, V. A.: acquisition of data, critical review of important intellectual content. All authors have read and approved the final version of the manuscript.

Ethics Approval: Not applicable.

Acknowledgements: The authors express gratitude to the administration of Minin University for supporting the research related to developing the model of managing the professional-personal development of a future specialist, as well as for constructive critical comments.

\section{REFERENCES}

A Career Guidance Policy and Strategy for Compulsory Schooling in Malta (2007).

https://education.gov.mt/en/resources/documents/policy\%20documents/career\%20guidance.pdf

Balobanova, T.N., Orlova, T.N., Pakhomova, O.F., \& Perfilyeva, E.N. (2015). Methodological recommendations for the organization and holding of parental meetings on career guidance. Saint Petersburg: LOIRO.

Batyshev, S.Ya. (1997). Professional pedagogy. Moscow: Assotsiatsiya "Professionalnoye obrazovaniye".

Bedov, A.N. (n.d.) Project approach in the process of activating the professional self-determination of adolescents. http://www.eduportal44.ru/npo/MPROFK/20132/\%D0\%91\%D0\%B5\%D0\%B4\%D0\%BE\%D0\%B2 \%D0\%90\%D0\%9D.doc $\underline{x}$

Blauberg, I.V. (1997). Integrity problem and systemic approach. Moscow: Editorial URSS.

Blinov, V.I., et al. (2014). Concept of organizational and pedagogical support of professional self-determination of students under continious education. Moscow: Federalniy institut razvitiya obrazovaniya, Pero.

Blinov, V.I., et al. (2018). Concept of support for professional self-determination in the context of the continuity of education. https://www.cposo.ru/federalnyj-uroven/1087-kontseptsiya-soprovozhdeniya-professionalnogosamoopredeleniya-obuchayushchikhsya-v-usloviyakh-nepreryvnosti-obrazovaniya

Career Education and Guidance in New Zealand Schools (2009). https://nzcurriculum.tki.org.nz/content/download/2767/35051/file/Career-guidelines-web.pdf

Careers guidance and access for education and training providers (n.d.).

https://assets.publishing.service.gov.uk/government/uploads/system/uploads/attachment data/file/672418/ Career s guidance and access for education and training providers.pdf

Career guidance and counseling (n.d.). http://unesdoc.unesco.org/images/0024/002480/248069E.pdf

Careers guidance in school, colleges and universities (n.d.).

http://researchbriefings.files.parliament.uk/documents/CBP-7236/CBP-7236.pdf

Career Guidance in Sweden (2015). https://www.uhr.se/globalassets/syv/utlandsvistelse/euroguidance/flerrapporter/career-guidance uppslag.pdf

Chistyakova, S.N., \& Zaharov, N. N. (1987). Professional guidance of schoolchildren: organization and management. Moscow: Pedagogika.

Educational and vocational guidance in Finland (n.d.).

http://cimo.fi/instancedata/prime product julkaisu/cimo/embeds/cimowwwstructure/15616 guidance in finland 2 009.pdf

Fedorov, A.A., Paputkova, G.A., Ilaltdinova, E.Y., Filchenkova, I.F., \& Solovyev, M.Y. (2017). Model for employersponsored education of teachers: Opportunities and challenges. Man in India, 97(11), 101-114.

Fyodorov, A.A., Paputkova, G.A., Filchenkova, I.F., Voronin, D.I., Bogorodskaya, O.V., Lebedeva, T.E., Nuriev, I.A., Balakin, M.A., \& Vasilyev, D.I. (2017). Information and educational service "Configurator of personal success" (mobile application). Chronicles of the Integrated Fund of Electronic Resources "Science and Education", 11(102), 8.

Gruzdeva, M.L., Prokhorova, O.N., Chanchina, A.V., Chelnokova, E.A., \& Khanzhina, E.V. (2018). Post-graduate information support for graduates of pedagogical universities. Advances in Intelligent Systems and Computing, 622, 143-151. 
Ilyashenko, L.K., Vaganova, O.I., Smirnova, Z.V., Sedykh, E.P., \& Shagalova, O.G. (2018). Implementation of heurist training technology in the formation of future engineers. International Journal of Mechanical Engineering and Technology, 9 (4), 1029-1035.

Jenschke, B., Schober, K., \& Langner, J. (n.d.) Career Guidance in the Life Course Structures and Services in Germany. https://www.euroguidance.eu/career-guidance-in-the-life-course-structures-and-services-ingermany/download/2014-career-guidance-in-the-life-course

Kazakevich, A.V. (n.d.) Pedagogical support of professional self-determination of Agricultural University students. https://cyberleninka.ru/article/n/pedagogicheskoe-soprovozhdenie-professionalnogo-samoopredeleniya-studentovagrarnogo-vuza

Klimov, E.A. (1996). Psychology of professional self-determination. Rostov-on-Don.

Kolesnikova, O.A., Krymova, N.A., \& Barkovskaya, S.V. (2011). System management of vocational guidance. Voronezh. Kondakov, I.M., \& Sukharev, A.V. (1989). Methodological foundations of foreign theories of professional development. Issues of Psychology, 5, 162.

Kostenko, O.A., Sevryukova, A.A., Ilyasov, D.F., \& Kostina, N.P. (2017). Early personal and professional selfdetermination of rural schoolchildren through educational tourism. Modern issues of science and education, 6. http://www.science-education.ru/ru/article/view?id=27244

Kozyreva, O.A. (n.d.) Main aspects of the Russian and foreign concepts of professional development. https://cyberleninka.ru/article/v/osnovnye-aspekty-otechestvennyh-i-zarubezhnyh-kontseptsiy-professionalnogorazvitiya

Kudryavtsev, T.V. (1986). Psychology of vocational training and education. Moscow: MEHI.

Kuzmina, N.V. (1990). Professionalism of a personality of a teacher and master of industrial training. Moscow: Vysshaya shkola.

Markova, A. K. (1996). Psychology of professionalism. Moscow: Vysshaya shkola.

Markova, S.M., Sedykh, E.P., Tsyplakova, S.A., \& Polunin, V.Y. (2018). Perspective trends of development of professional pedagogics as a science. Advances in Intelligent Systems and Computing, 622, 129-135.

Markova, S.M., Svadbina, T.V., Sedykh, E.P., Tsyplakova, S.A., \& Nemova, O.A. (2018). Methodological basis of vocational pedagogical education. Astra Salvensis, 6, 769-777.

McMahon, M. (n.d.) New Trends in Theory Development in Career Psychology.

https://www.springer.com/cda/content/document/cda downloaddocument/9781461494591-c1.pdf?SGWID=0-0-451445146-p176270821

Mishina, N.V., \& Yavgildina, Z.M. (2016). Activity approach to the formation of vocational orientation of adolescents during additional education. Bulletin of KazGUKI, 3. https://cyberleninka.ru/article/v/deyatelnostnyy-podhod-kformirovaniyu-professionalnoy-orientatsii-podrostkov-v-usloviyah-dopolnitelnogo-obrazovaniya

Myalkina, E.V. (2011). Developing a competitive specialist in the economic sphere at university. Nizhniy Novgorod: NGPU named after K. Minin.

Oriol, M.D., Brannagan K., Ferguson, L.A., \& Pearce, P.F. (n.d.) Understanding Career Trajectory: A Degree Alone is Not Enough.https://www.researchgate.net/publication/305257345 Understanding Career Trajectory A Degree Alone i s Not Enough

Panasyuk, V.P. (2015). Vocational guidance work and profile education in a modern school: experience and innovations. Saint Petersburg: LOIRO.

Parsons, Frank (1909). Choosing a vocation. Boston and New York: Houghton Mifflin. https://archive.org/details/choosingavocati01parsgoog

Pisareva, S.A. (2005). Designing an educational environment for profile education: methodological recommendations for a selective course. Saint Petersburg: RGPU.

Povarenkov, Yu.P. (1991). Psychology of professional development of a personality. Kursk: KROST.

Povarenkov, Yu.P. (2002). Psychological content of professional development of a person. Moscow: URAO.

Prokhorova, M.P., \& Sedykh, E.P. (2016). Designing an individual educational route for a bachelor in the process of mastering managerial disciplines. Azimuth of scientific research: Pedagogy and Psychology, 3(16), 124-127. 
Pryazhnikova, E.Yu., \& Pryazhnikov, N.S. (2010). Professional guidance. Moscow: Akademiya.

Rezapkina, G.V. (2012). Express diagnostics of professional interests and inclinations of 6-7 and 8-9 grades' schoolchildren. Klassnyj rukovoditel', 4, 47-107. http://psyjournals.ru/authors/47574.shtml

Rezapkina, G.V. (2013). Professional guidance: new horizons. Employee service, 1, 66-70.

Rezapkina, G.V., Suvorova, L.N., Romanova, N.F., Antonicheva, S.I., \& Tupikova, E.E. (2015). To help career counselors. Yoshkar-Ola.

Ricci, L., \& Boccardi, V. (n.d.) Effective use of educational and vocational guidance services in distance education: the experience of USGM. Italy.

https://ivx.jyu.fi/dspace/bitstream/handle/123456789/22919/ricci boccardi.pdf?sequence=1

Romanova, E.S. (2013). Organization of career guidance at school. Moscow: Akademiya.

Semarkhanova, E.K., Bakhtiyarova, L.N., Krupoderova, E.P., Krupoderova, K.R., \& Ponachugin, A.V. (2018). Information technologies as a factor in the formation of the educational environment of a university. Advances in Intelligent Systems and Computing, 622, 179-186.

Sergeev, I.S. (2017). Designing a system of organizational and pedagogical support for the professional selfdetermination of students under vertically integrated continuous education. Moscow: Pero.

Smirnova, Z.V., Mukhina, M.V., Kutepova, L.I., Kutepov, M.M., \& Vaganova, O.I. (2018). Organization of the research activities of service majors trainees. Advances in Intelligent Systems and Computing, 622, 187-193.

Stefansdottir, D. (n.d.) Educational and vocational guidance in Iceland. Euroguidance Centre, Iceland. https://www.erasmusplus.is/media/euroguidance/Educational-and-vocational-guidande-in-Iceland.pdf

Tartur, Yu.G. (2004). Competence approach in describing results and designing standards for higher professional education. http://fgosvo.ru/uploadfiles/npo/20120325221547.pdf

Tolstoguzov, S.N. (2015). Education abroad. Obrazovanie i nauka, 1(120), 151-165. https://doi.org/10.17853/19945639-2015-1-151-165

Troitskaya, I.I. (n.d.) Competence approach in the vocational guidance of 8-9 grades schoolchildren at the lessons of additional education: methodological aspect. https://cyberleninka.ru/article/v/kompetentnostnyy-podhod-vprofessionalnoy-orientatsii-uchaschihsya-8-9-klassov-na-urokah-dopolnitelnogo-obrazovaniya-metodicheskiy

Vehbi, Bayhan (2014). The role and function of school sociologist in guidance system. European Journal of Research on Education, 2(2), 271-275. http://iassr2.org/rs/020231.pdf

Vocational guidance education in full-time compulsory education (n.d.). http://www.nefmi.gov.hu/download.php?doclD=2332

Zapesotskaya, N.A. (2006). Project culture as a factor of professional success of a specialist in social and communicative sphere. Bulletin of Moscow State University of Culture and Arts, 3, 124-127.

Zeer, E.F. (2005). Psychology of professions. Moscow: Akademicheskiy proyekt; Fond "Mir".

Zeer, E.F., \& Symanyuk, E.E. (2014). Theoretical and applied bases for predicting personal professional future. Fundamental research, 9(8), 1863-1869. http://www.fundamental-research.ru/ru/article/view?id=35157

Zhitkova, V.A. (2012). Problems of improving the quality of training and demand for university graduates under economic modernization. In: Problems and prospects of development of education in Russia: Collection of works of XV International scientific-practical conference. Novosibirsk: NGTU.

Zimnyaya, I.A. (n.d.) Key competences as a result-oriented basis of the competence approach in education.

http://fgosvo.ru/uploadfiles/npo/20120325214132.pdf

Received: 21 April 2021 | Accepted: 5 August 2021 | Published: 29 August 2021 